\title{
Prevalence and rapid identification of Salmonella Infantis in broiler production in Turkey
}

\author{
Özlem Şahan YAPICIER ${ }^{1, a, \bowtie}$, Barış SAREYYÜPOĞLU ${ }^{2, b}$ \\ ${ }^{1}$ Mehmet Akif Ersoy, Faculty of Veterinary Medicine University Department of Microbiology, Burdur, TURKEY; ${ }^{2}$ Ankara \\ University, Faculty of Veterinary Medicine, Department of Microbiology, Dışkapı, Ankara, TURKEY \\ ${ }^{\mathrm{a} O R C I D: 0000-0003-3579-9425 ; ~ ' ~ O R C I D: ~ 0000-0002-2212 ~} 2610$

Corresponding author: ozlemsahan @ mehmetakif.edu.tr
Received date: 03.07.2020 - Accepted date: 05.03.2021

\begin{abstract}
In the present study, the prevalence of Salmonella enterica subsp. enterica serovar Infantis ( $S$. Infantis) and other serovars were investigated in samples collected from commercial broiler chicken flocks in Turkey according to the ISO 6579:2002/Amd 1:2007, Annex D, standard method. Furthermore, previously developed $S$. Infantis-specific polymerase chain reaction (PCR)-based methods with primers targeting fljB, fliC, IMP1-IMP2-IMP3 and sinI were conducted in different media (BPW, MRSV, MKTTN, XLD, and XLT 4 agars) and during four incubation stages $(6,12,18$, and $24 \mathrm{~h}$ ) of the ISO 6579 procedure to develop rapid and reliable diagnosis method. One-hundred thirty-three (15.6\%) Salmonella strains were isolated from a total of 848 samples (240 cecal swabs, 200 cloacal swabs, 190 intestinal contents, 59 feed, 39 dust, and 120 litter). The serovar distribution of isolated strains was as follows: $S$. Infantis, 88.70\%; S. Agona, 2.3\%; S. Kentucky 1.50, S. Hadar 1.50, and S. Tennessee 1.50; S. Mbandaka $0.75 \%, S$. Montevideo $0.75 \%, S$. Enteritidis $0.75 \%, S$. Adelaide $0.75 \%, S$. Liverpool $0.75 \%$, and $S$. Derby $0.75 \%$. Primers targeting $f l j B$, fliC, and IMP1-IMP2-IMP3 were not able to detect all $S$. Infantis isolates, therefore, a novel PCR technique was developed and validated in the study. It was concluded that it is a fast, reproducible and low-cost alternative to the gold standard method by detecting the $S$. Infantis isolates on the 3rd day at the earliest by PCR ( $\sin I$ PCR). using primers specific to $S$. Infantis species.
\end{abstract}

Keywords: Broilers, ISO 6579, PCR, Salmonella Infantis.

\section{Türkiye'deki broyler üretiminde Salmonella Infantis'in yaygınlığı ve hızlı tanısı}

Özet: Bu çalışmada, Türkiye'de bulunan ticari tavuk sürülerinden toplanan toplam 848 örnek (240 sekal ve 200 kloakal svap, 190 bağırsak içeriği, 59 yem, 39 toz ve 120 altlık), ISO 6579: 2002 / Amd 1: 2007, Ek D standart yöntemine göre $S$. Infantis ve diğer serovarların prevalansı yönünden araştırıldı. Buna ek olarak, hızlı ve güvenilir bir teşhis amacıyla, $S$. Infantis'e özgü genleri $(f l j B, f l i C$, IMP1-IMP2-IMP3 ve $\operatorname{sinl}$ ) hedefleyen PCR temelli metodlar (PCR ve multipleks PCR), ISO 6579 prosedürünün farklı inkübasyon aşamaları $(6,12,18$ ve 24 saat) ve ortamlarında (BPW, MSRV, MKTTN, XLD ve XLT 4 agarları) kullanıldı. Toplam 848 örnekten 133(\%15,6) Salmonella suşu izole edildi. İzole edilen suşların serovar dağılımı, S. Infantis \% 88,70; S. Agona \% 2,3; S. Kentucky \% 1,50, S. Hadar \% 1,50 ve $S$. Tennessee \% 1,50; S. Mbandaka \% 0,75, S. Montevideo \% 0,75, S. Enteritidis \% 0,75, S. Adelaide \% 0,75, $S$. Liverpool \% 0,75 ve $S$. Derby \% 0,75'dir. Bu çalışmada, fljB, fliC ve IMP1-IMP2-IMP3 primerleri tüm $S$. Infantis izolatlarını tespit edemedi ve bu nedenle yeni bir PCR tekniği geliştirilip validasyonu yapıldı. $S$. Infantis türüne spesifik primerlerler yapılan (sinI PCR) PCR ile $S$. Infantis izolatlarını en erken 3. günde tespit ederek altın standart yönteme alternatif hızlı, tekrarlanabilir ve düşük maliyetli metot olduğu sonucuna varıldı.

Anahtar sözcükler: Broyler, ISO 6579, PCR, Salmonella Infantis.

\section{Introduction}

Salmonella agents cause the most common foodborne diseases in the world (48). Some serotypes show host-specific characteristics, but the vast majority cause cross-species infections. Hence, warm-blooded animal origin serotypes are considered as potential pathogens for humans (37). Salmonella nomenclature is complex in the Enterobacteriaceae family, and there are more than 2500 serotypes according to the KauffmanWhite scheme (20).

$S$. enterica subsp. enterica serovar Typhimurium ( $S$. Typhimurium) and $S$. enterica subsp. enterica serovar Enteritidis ( $S$. Enteritidis) are the most common serotypes leading to Salmonellosis in poultry $(9,12,44)$. However, in the past two decades, studies in developing countries also in Turkey have reported the dominance of these two 
serotypes has gradually decreased, while the frequency of other serotypes, especially Salmonella enterica subspecies enterica serovar Infantis ( $S$. Infantis), have increased (3, 24, 46). Surveys conducted by the European Food Safety Authority (EFSA) have shown that the isolation rates for $S$. Infantis originating from broiler chickens and carcasses in the EU, have recently been emerging (9-11). According to the National Salmonella Control Program, $S$. Infantis is the most frequently isolated serovar in Turkey (30).

Diagnosis of Salmonella infections is based on ISO 6579:2002/Amd 1:2007, Annex D, standard methods and this procedure takes approximately 11 days to complete (17-19). Gold standard Salmonella detecting method may result in an increased false-negative rate, which under an on-farm hazard analysis critical control point program would lead to no action when a corrective action is required (25). Therefore, many laboratories around the world have supported molecular methods to shorten this method, which requires intensive labour and experienced staff. During the past decade, there have been many advances in the molecular detection of Salmonella, especially polymerase chain reaction (PCR)-based methods [e.g., conventional and real-time] $(19,28)$, and several previous studies have used several genes, such as invA, invE, himA, phoP $(23,37)$ as targets for PCR investigation of Salmonella DNA in natural environmental and faecal samples.

Routine PCR-based testing and identification of Salmonella in diagnostic and microbiology laboratories must be rapid, reliable, and cost-effective (6, 22). Salmonella PCR assays have been combined with preenrichment, nonselective, and/or selective enrichment stages required to improve sensitivity, elimination, and identification of PCR-inhibitory substances. Therefore, many have been successful in detecting Salmonella DNA following a minimum 6 to $8 \mathrm{~h}$ or 24 to $30 \mathrm{~h}$ precultivation step $(15,33,42-44)$. The present study investigated the prevalence of $S$. Infantis and other serovars in samples (intestinal content, feed, dust, litter, cecal and cloacal swabs) from commercial broiler chicken flocks and different field materials in Turkey. In addition, $S$. Infantisspecific PCR-based techniques with primers targeting different genes using different media during four incubation stages of the ISO 6579 procedure were used to develop an alternative molecular diagnostic method that is rapid and reliable.

\section{Materials and Methods}

Salmonella strains: To investigate the specificity of PCR assays, Infantis, Liverpool, Enteritidis, Mbandaka, Typhimurium, Gallinarum, Heidelberg, Agona, Newport, Stanleyville, Hadar, Colombo, Muenchen, Kentucky, Virchow, and Anatum serovars were used as target control strains and obtained from Ankara University Veterinary Faculty, Department of Microbiology culture collection.
Strains were kept at $4{ }^{\circ} \mathrm{C}$ in stock agar, inoculated in tryptic soy broth (TSB), and incubated for 18-24 h at 37 ${ }^{\circ} \mathrm{C}$ prior to PCR.

Sampling procedure: A total of 848 samples (240 cecal swabs, 200 cloacal swabs, 190 intestinal contents, 59 feed, 39 dust, and 120 litter) were collected from 27-38day-old broilers in 238 broiler houses $(11,000-90,000$ poultry capacity) and 48 slaughterhouses in three different regions (Southeastern Anatolia, Marmara and Black Sea) of Turkey. Each broiler house was traversed in a zigzag pattern to ensure random collection of litter samples around feed lines, water lines, and side areas using sterile drag swabs. Sterile sponge swabs were used for random sampling of dust across feeders, drinkers, and walls of each poultry house. At least $25 \mathrm{~g}$ of feed samples were collected in sterile sampling bottles. Cloacal swabs were collected from recently deceased animals in farms using Amies transport medium. Intestinal contents were collected in faecal cups, and cecal swabs were collected in Whirl-Pak bags after evisceration in the slaughterhouses. At least five cloacal and cecal swabs were pooled in sterile bags. All samples were cooled to $4-8{ }^{\circ} \mathrm{C}$ in an icebox and immediately transported to the Salmonella Research Laboratory in the Department of Microbiology, Faculty of Veterinary Medicine, Ankara University for processing.

Isolation and Identification: All samples were analysed for Salmonella using ISO 6579:2002/Amd 1:2007. Specifically, samples were inoculated in buffered peptone water (BPW) as pre-enrichment medium and incubated at $37^{\circ} \mathrm{C}$ for $18-24 \mathrm{~h}$. After incubation, samples were transferred to Muller-Kauffmann tetrathionatenovobiocin broth (MKTTN) and modified semi-solid Rappaport-Vassiliadis (MSRV) medium and enriched for $18-24 \mathrm{~h}$ at $37^{\circ} \mathrm{C}$ and $24 \mathrm{~h}$ at $41.5^{\circ} \mathrm{C}$, respectively $(16,17$, 19). The cultures obtained were plated onto xylose lysine deoxycholate (XLD) and xylose lysine Tergitol-4 (XLT 4$)$, incubated at $37^{\circ} \mathrm{C}$, and examined after $24 \mathrm{~h}(16,17,19)$. All presumptive Salmonella colonies were characterized biochemically (triple sugar iron (TSI), $\mathrm{H}_{2} \mathrm{~S}$, gas formation, Voges Proskauer (VP), urea, lysine decarboxylase, and $\beta$ galactosidase tests) $(16,17,19-21)$.

Serotyping: The serogroup and serotyping of the strains that are biochemically compatible with Salmonella spp. were made by slide agglutination using polyvalent and monovalent Salmonella "O" and "H" antisera (Statens Serum Institut, Denmark and Denka Seiken, Japan) and serotyped according to the Kauffman-White scheme (16).

DNA extraction: Samples were taken at 6, 12, 18, and $24 \mathrm{~h}$ during incubation at different stages of the ISO 6579 method (before inoculation, pre-enrichment, and selective enrichment) (Figure 1). DNA extraction was performed according to the instructions of the GeneJET Genomic DNA Purification Kit and QIAamp DNA Stool Kit. DNA for use as template DNA was stored at $-20{ }^{\circ} \mathrm{C}$ until amplification. 


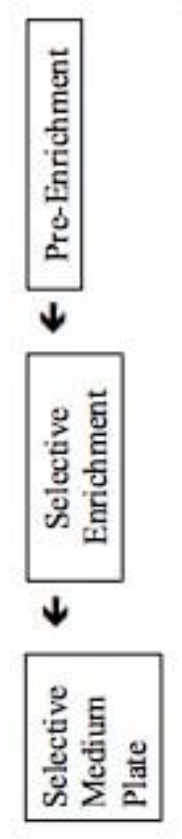

Litter Ceacal swab Cloacal swab Intestinal content Feed Dust $\rightarrow$ PCR

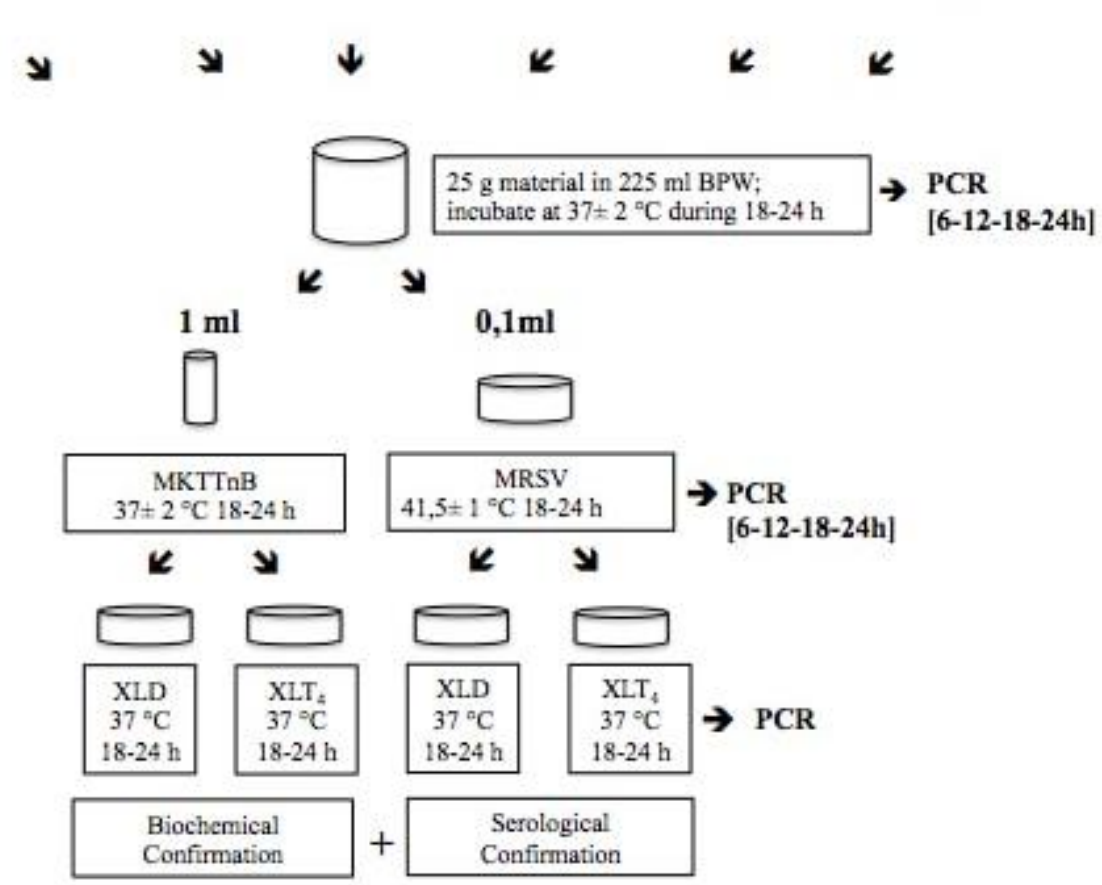

Figure 1. Flowchart of the diagnostic method of $S$. Infantis.

Table 1. Primer used for conventional PCR determination of $S$. Infantis.

\begin{tabular}{|l|l|l|l|}
\hline NCBI accession no. & Primer name & Primer sequence (5' - 3') & Amplicon size (bp) \\
\hline J03391.1 & $\operatorname{sinI}$ & $\begin{array}{l}\text { CGTTGCGTGAAACCATAACT } \\
\text { CTTACGACGAGTTGCATGGG }\end{array}$ & 201 \\
\hline
\end{tabular}

Sequences: For specific detection of $S$. Infantis DNA in field samples, fljB, fliC $(17,31)$, and IMP1-IMP2-IMP3 (1) primers were used in conventional and multiplex PCR, respectively, using methods described previously (1). An additional invA PCR was used as a confirmatory test for detection of Salmonella (43).

Primer design and PCR assay optimization: A new primer pair specific to a 201-bp sequence of $\operatorname{sinI}(S$. Infantis modification methylase gene; Accession no. J03391.1) of $S$. Infantis (Table 1) was designed using Primer 3 software (41). PCR amplification was optimized and the PCR assay was carried out in a $25 \mu \mathrm{L}$ reaction solution containing $3 \mu \mathrm{L}$ of $\mathrm{MgCl}(25 \mathrm{mM}), 0.5 \mu \mathrm{L}$ dNTP $(10 \mathrm{mM}), 10 \mathrm{pmol}$ of primers, and $0.2 \mu \mathrm{L}$ Taq polymerase $(5 \mathrm{U} / \mu \mathrm{L})$. The following cycling conditions were used: 3 min at $94{ }^{\circ} \mathrm{C}$, followed by 30 cycles of $1 \mathrm{~min}$ at $94{ }^{\circ} \mathrm{C}$ (denaturation) and $1 \mathrm{~min}$ at $54{ }^{\circ} \mathrm{C}$ (primer annealing), 1 $\min$ at $72{ }^{\circ} \mathrm{C}$ (extension), and $7 \mathrm{~min}$ at $72{ }^{\circ} \mathrm{C}$ (final extension).

Specificity and detection limit: The detection limit was determined using a 10-fold serial dilution of a broth culture (in BPW incubated for $24 \mathrm{~h}$ at $37^{\circ} \mathrm{C}$ ) of one of the $S$. Infantis strains sequenced for primer design. The CFU number was determined by quantitative culture of these dilutions (26).

Detection of $S$. Infantis in naturally contaminated samples: The validity and reliability of the $\operatorname{sinI}$ PCR assay for $S$. Infantis was tested to confirm that the method was a rapid alternative to the reference culture method. Naturally contaminated samples $(n=16)$ consisted of 5 litter, 4 cecum swabs, 1 cloaca swab, 1 intestinal content, 3 feed, and 2 dust samples collected from broiler houses (two broiler houses from two different geographic locations) with a previous history of being $S$. Infantispositive and -negative and examined according to ISO $6579(16,17,19)$ and PCR in parallel. Samples were taken at $6,12,18$, and $24 \mathrm{~h}$ during incubation at different stages (initial, pre-, and selective enrichment) of the culture method for PCR analysis as described above. The results of ISO 6579 and PCR methods were compared.

\section{Results}

Isolation and identification: A total of 133 (15.6\%) Salmonella strains were isolated from litter 56/120 (46.7\%), feed 23/59 (39\%), cloacal swabs 21/40 (52.5\%), cecal swabs $15 / 240(6.25 \%)$, intestinal content $14 / 190$ 
(7.47\%), and dust 4/39 (10.25\%). We identified 11 different Salmonella serotypes from the 133 Salmonella isolates. The most common serotype was $S$. Infantis 118 (88.70\%) followed by $S$. Agona 3 (2.3\%); S. Kentucky 2 (1.50\%), S. Hadar $2(1.50 \%)$, and $S$. Tennessee $2(1.50 \%)$; and $S$. Mbandaka $1(0.75 \%), S$. Montevideo $1(0.75 \%), S$. Enteritidis $1(0.75 \%), S$. Adelaide $1(0.75 \%), S$. Liverpool $1(0.75 \%)$, and $S$. Derby $1(0.75 \%)$. S. Infantis was isolated from all sample types; $S$. Kentucky, S. Montevideo, $S$. Mbandaka, and $S$. Enteritidis were isolated from litter; $S$. Agona was isolated from litters and intestinal contents; $S$. Hadar and $S$. Adelaide were isolated from cecal swabs; and $S$. Liverpool and $S$. Derby were isolated from feed. The obtained isolation rate of $S$. Infantis was $39.16 \%$ $(47 / 120)$ in litters, $10.25 \%$ (4/39) in dust, $10.5 \%$ (21/200) in cecal swabs, $6.84 \%(13 / 190)$ in intestinal content, and $35.59 \%(21 / 59)$ in feed.

Determination of PCR assay specificities: In studies determining the specificity of conventional and multiplex PCR techniques, $f l j B$ and $f l i C$ primers were not able to detect all $S$. Infantis isolates, nonspecific band profiles were observed, and IMP1-IMP2-IMP3 primers gave common bands with $S$. Infantis, $S$. Liverpool, $S$. Enteritidis, $S$. Mbandaka, $S$. Typhimurium, and $S$. Gallinarum. Because these results conflicted, new primers for S. Infantis DNA detection were designed. Conventional PCR was performed on a total of 21 Salmonella serotypes [S. Infantis $(n=6) ; S$. Typhimurium $(n=2) ; S$. Heidelberg, $S$. Agona, $S$. Newport, $S$. Stanleyville, S. Hadar, S. Mbandaka, S. Colombo, $S$.
Muenchen, $S$. Kentucky, $S$. Enteritidis, $S$. Virchow, $S$. Anatum, and $S$. Mbandaka (all $n=1)]$ with novel sinIF and sinIR primers. Designed primers amplified all $S$. Infantis serotypes, while no PCR product was obtained with other serotypes (Figure 2). The diagnostic specificity was accepted to be $100 \%$, as no false-negative or -positive results were obtained from the PCR.

S. Infantis PCR detection limit: The detection limit of $S$. Infantis following optimization of the PCR assay was $1 \times 10^{3} \mathrm{CFU} / \mathrm{mL}$.

Salmonella detection using invA: InvA primers (605-bp DNA fragments) could be amplified from all Salmonella isolates tested by conventional PCR. Therefore, all Salmonella isolates were detected at a genus level.

Detection of $S$. Infantis in naturally contaminated samples: A total of 7 (2 litter, 1 cecal swabs, 1 cloacal swab, 1 feed, 1 intestinal content, and 1 dust sample) out of 16 naturally contaminated samples gave positive results for $S$. Infantis by both culture and PCR methods. PCR performed during the pre-enrichment and selective enrichment stages, it was determined that the $S$. Infantis rates detected by the design primer at the 6,12 and $18^{\text {th }}$ hours varied between $0-42.85 \%$ and $28.57-57.14 \%$ in the sampling performed at the $24^{\text {th }}$ hour. On the 3 rd day of isolation Salmonella-suspected colonies occurred in XLD and $\mathrm{XLT}_{4}$. The sinI PCR assay detected $100 \%$ of culturepositive $S$. Infantis (Figure 3) correctly on day 3, without false-positive or -negative test results (Table 2).

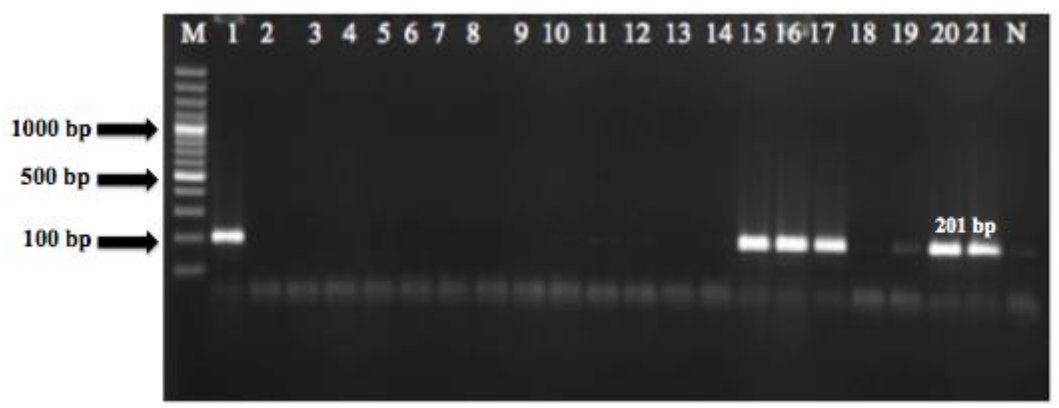

Figure 2. PCR assay was performed using sinIF and sinIR primers (M: 100bp marker, 1, 15-17, 20, 21; S. Infantis, 2; S. Heidelberg, 3; $S$. Agona, 4; $S$. Newport, 5; S. Stanleyville, 6; S. Hadar, 7; $S$. Mbandaka, 8, 18; S. Typhimurium, 9; S. Colombo, 10; $S$. Muenchen, 11; $S$. Kentucky, 12; S. Enteritidis, 13; S. Virchow, 14; $S$. Anatum, 19; S. Mbandaka; N: negative control).

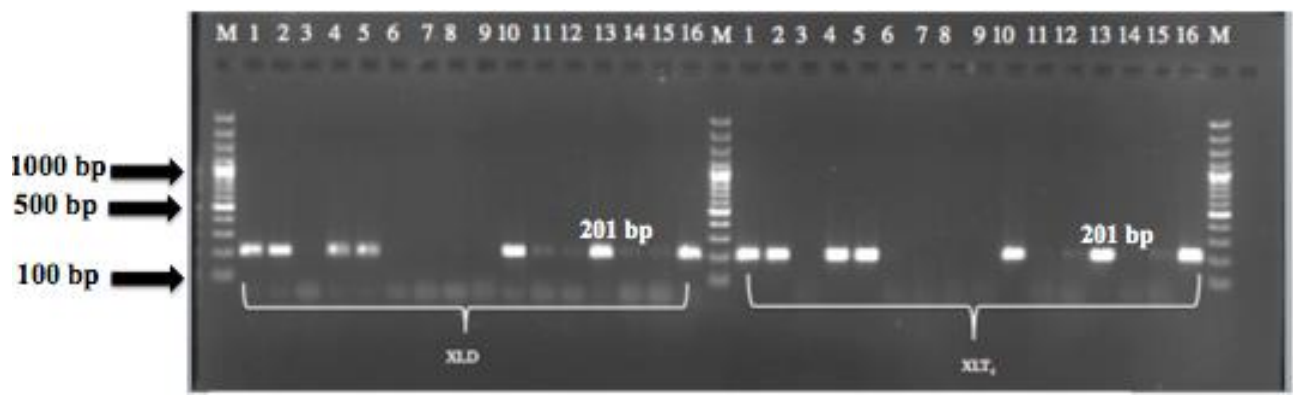

Figure 3. $S$. Infantis isolates were detected using $\sin I F$ and $\operatorname{sinIR}$ primers on the XLD and XLT4 agar (M: 100 bp marker; 1,2 , $4,5,10,13,16 ; S$. Infantis; 3,6-8,11,12,14,15; negative). 
Table 2. Detection of $S$. Infantis in naturally contaminated samples.

\begin{tabular}{|c|c|c|c|}
\hline Test day & Test Time (hour) & \multicolumn{2}{|c|}{ ISO 6579 Medium / PCR Results; Positives(\%) } \\
\hline Day 0 & 0 & \multicolumn{2}{|c|}{ Direct Analysis (Negative) } \\
\hline \multirow{4}{*}{ Day 1} & 6th & \multicolumn{2}{|c|}{ BPW (Negative) } \\
\hline & 12 th & \multicolumn{2}{|c|}{ BPW $(1 / 7)$} \\
\hline & 18th & \multicolumn{2}{|c|}{$\mathrm{BPW}(2 / 7)$} \\
\hline & 24th & \multicolumn{2}{|c|}{$\mathrm{BPW}(2 / 7)$} \\
\hline \multirow{4}{*}{ Day 2} & 6th & $\operatorname{MSRV}(1 / 7 ; 14.8 \%)$ & MKTTN (Negative) \\
\hline & 12th & MSRV (1/7) & MKTTN (Negative) \\
\hline & 18th & MSRV (3/7) & $\operatorname{MKTTN}(2 / 7 ; 28.57 \%)$ \\
\hline & 24th & $\operatorname{MSRV}(4 / 7 ; 57.15 \%)$ & $\operatorname{MKTTN}(2 / 7 ; 28.57 \%)$ \\
\hline Day 3 & - & XLD $(7 / 7 ; 100 \%)$ & $\mathrm{XLT}_{4}(7 / 7 ; 100 \%)$ \\
\hline Day 4 & - & \multicolumn{2}{|c|}{ Nutrient Agar $(7 / 7 ; 100 \%)$} \\
\hline Day 11 & - & \multicolumn{2}{|c|}{ Serotype Identification $(7 / 7 ; 100 \%)$} \\
\hline
\end{tabular}

BPW: Buffered Peptone Water; MSRV: MKKTN; XLD; XLT4.

\section{Discussion and Conclusion}

Poultry production is increasing every year in the world and becoming more common than any other animal protein source due to heightened consumption. Thus, intense efforts are being made to increase the quality standards of poultry products. Turkey is the $8^{\text {th }}$ largest broiler meat (2.25 million tons) and egg producer (>20 billion chicken eggs annually) and the $6^{\text {th }}$ largest poultry meat exporter (425,000 tons) [FAO report, April 2018] in the world (51). Regarding its \$6-billion-dollars annual endorsement, the poultry sector has a significant share in overall animal production in Turkey. According to data obtained from a study investigating the epidemiology of Salmonella serotypes carried out from 2014 to 2017 as part of the "Project for the Development of Monitoring and Control Programs for Salmonella from Poultry and Food" in cooperation with the Faculty of Veterinary Medicine, Ankara University (Turkey) and the Ministry of Food Agriculture and Livestock and supported by the Scientific and Technological Research Council of Turkey (TUBITAK, 113R036/113R037), a "National Control Program for Salmonella" was established and a Salmonella Research Laboratory in the Department of Microbiology, Faculty of Veterinary Medicine, Ankara University, was authorized as the National Salmonella Reference Laboratory (30).

$S$. Infantis has become increasingly important in recent years due to increased isolation rates from environmental samples from poultry farms in the European Union and other countries. Furthermore, recent data also showed that $S$. Infantis accounts for $36.5 \%$ and $55.7 \%$ of all serotyped Salmonella isolates from broiler flocks (10).

Salmonella can persist and even multiply in remaining organic matter and show the ability to adapt the special conditions of poultry houses $(13,38)$. Therefore, significant resources are spent on cleaning and disinfection of poultry houses and it may not be easy to determine which proper control measures need to be taken. Recent studies highlight that broiler production is a critical point of Salmonella contamination worldwide, and Turkey is no exception. Concerning the distribution of Salmonella serotypes in present broiler samples, the predominant serotype was $S$. Infantis $(88.72 \%)$ followed by $S$. Agona $(2.25 \%) ; S$. Kentucky, $S$. Hadar, and $S$. Tennessee (all 1.50\%); and $S$. Mbandaka, S. Montevideo, $S$. Enteritidis, $S$. Adelaide, $S$. Liverpool, and $S$. Derby (all $0.75 \%$ ). Notably, these findings suggest that $S$. Infantis as a dominant serovar may have inhibited colonization of other serovars, thereby enabling it to continuously maintain a higher prevalence rate in those flocks. In contrast to other dominant serovars like $S$. Enteritidis and $S$. Typhimurium which can usually be overcome within a few flock production cycles, unfortunately $S$. Infantis persistence are constantly reported in farms and it is well known that still remain difficult to trace $(14,35)$. Another concern from Berchieri and Barrow (1990) reported that strains of $S$. Infantis colonized the chicken alimentary and produced inhibition of a wider range of serotypes (4). Several other studies have investigated the presence of $S$. Infantis in broiler production and revealed a high prevalence in Poland [8\%] (40), Hungary [2.5\%] (32) and in the last two years period number of positive flocks has increased by more than $100 \%$ in Slovenia (35). S. Infantis as the main serovar in different countries in Asia $(34,39)$, although in some European countries was $S$. Typhimurium and $S$. Enteritidis $(8,45,50)$. In Japan, trend in the number of serotypes are S. Infantis $57.6 \%, S$. Manhattan $40.3 \%$, and $S$. Schwarzengrund $2.1 \%$ (7). The difference in serovar prevalence by region or country could be due to 
geographical differences and husbandry practices in occurrence and dominance.

$S$. Infantis can be isolated at different rates from different samples, both environmental and directly from birds. In this study level of detection is consistent with other reports, where $S$. Infantis in broiler chicken was $21.97 \%$ and $43 \%$ in fecal samples $(25,26)$ and $12.12 \%$ in feed (31). Taken together, these results indicate that environmental samples, such as from litter and dust, may be more useful than animal cloacal and cecal swabs for the routine screening and identification of Salmonellapositive flocks at the house level (36), while colonization and/or contamination can be measured through fecal sampling (15).

In the present study, PCR was first performed with primers designed by researchers who claimed their methods specifically detected $S$. Infantis $(1,21)$. Nevertheless, nonspecific bands were obtained with $f l i C$ and $f l j B$ primers, while the multiplex PCR technique, based on the simultaneous amplification of three different genomic regions specific to $S$. Infantis, produced common bands in PCRs with $S$. Enteritidis, $S$. Typhimurium, $S$. Mbandaka, and $S$. Liverpool (1). Additionally, it was seen that both methods performed with environmental samples failed to detect the $S$. Infantis accurately and sensitively. In this study, we achieved the detection limit of $S$. Infantis as $1 \times 10^{3} \mathrm{CFU} / \mathrm{mL}$, however, the method developed by Kardos et al. (21) determined $S$. Infantis at the level of $10^{5}$ $\mathrm{cfu} / \mathrm{ml}^{-1}$ and sensitivity study was not conducted by Akiba et al. (1) These results not only demonstrate the need for new primer pairs with greater specificity for $S$. Infantis, but also the strength of the novel sinI PCR assay, which detected all culture-positive $S$. Infantis correctly and early (on day 3), without false-positive or -negative test results. The latter is most significant because previous $S$. Infantis DNA detection methods involve live cells in colonies formed on XLD and $\mathrm{XLT}_{4}$ agars, rather than DNA from inactivated and/or injured $S$. Infantis bacteria in the growth media from the early steps of the ISO procedure.

The invA gene was detected in all Salmonella strains isolated in the study. Invasive invA is necessary for Salmonella virulence and has been studied by many researchers $(28,29)$. At the same time, the amplification of the invA gene of potential pathogenic Salmonella strains is accepted as the international standard procedure for the detection of Salmonella species (2).

The ISO 6579 standard Salmonella isolation and identification procedure lasts $11 \mathrm{~d}$. Herein, samples were taken at $6,12,18$, and $24 \mathrm{~h}$ during incubation at different stages of the ISO 6579 method and then conventional PCR was performed with designed primers and DNA loss (false-negative PCR results) was observed during the preenrichment and selective enrichment stages. This loss is thought to have been caused by PCR inhibition due to the sample composition and/or media content. In the present study to specifically isolate DNA from the environment, it was found important to apply internal control in the initial stages of diagnosis, using 10-fold dilution of materials and / or DNA, and / or modification of DNA extraction or use of magnetic or immunomagnetic separation techniques.

Overall, the present study reports development of a novel PCR technique that was validated for the detection of $S$. Infantis isolates during different stages of the ISO 6579 procedure. Moreover, this new analysis method provides a rapid, repeatable, and economical alternative to the gold standard. It is possible that this same strategy could be applied to other serotypes and has the potential to produce much more effective molecular assays in future, such as the real-time multiplex detection of most prevalent serotypes together and in a shorter time frame.

\section{Acknowledgements}

This study was derived from the $\mathrm{PhD}$ thesis of the first author. We would like to thank Prof. Dr. Mehmet Akan (Department of Microbiology, Faculty of Veterinary Medicine, Ankara University, Ankara, Turkey) for his valuable contributions (material maintenance from the field and professional advice on the study) to the study.

\section{Financial support}

This research received no grant from any funding agency/sector.

\section{Ethical Statement}

This study was approved by Ankara University and the institutional ethics committee for the local use of animals in experiments (Protocol No. 2012-16-101). Permission to collect samples was obtained from the poultry houses and slaughterhouses.

\section{Conflict of Interest}

The authors declared that there is no conflict of interest.

\section{References}

1. Akiba M, Kusumoto M, Iwata T (2010): Rapid identification of Salmonella enterica serovars, Typhimurium, Choleraesuis, Infantis, Hadar, Enteritidis, Dublin and Gallinarum, by multiplex PCR. J Microbiol Methods, 85, 9-15.

2. Amini K, Zahraci TS, Gholamreza N, et al (2010): Molecular detection of invA and spv virulence genes in Salmonella Enteritidis isolated from human and animals in Iran. Afr J Microbiol Res, 4, 2202-2210.

3. Asai T, Ishihara K, Harada K, et al (2007): Long-term prevalence of antimicrobial-resistant Salmonella enterica subspecies enterica serovar Infantis in the broiler chicken industry in Japan. Microbiol Immunolol, 51, 111-115. 
4. Berchieri A, Barrow PA (1990): Further studies on the inhibition of colonization of the chicken alimentary tract with Salmonella typhimurium by pre-colonization with an avirulent mutant. Epidemiol Infect, 104, 427-441

5. Carraminana JJ, Rota C, Agustin I, et al (2004): High prevalence of multiple resistance to antibiotics in Salmonella serovars isolated from a poultry slaughterhouse in Spain. Vet Microbiol, 104, 133-139.

6. Correa IMO, Pereire LQ, Silva IGO, et al (2018): Comparison of three diagnostic methods for Salmonella enterica serovars detection in chicken rinse. Pesq Vet Bras, 38, 1300-1306.

7. Duc VM, Nakamoto Y, Fujiwara A, et al (2019): Prevalence of Salmonella in broiler chickens in Kagoshima, Japan in 2009 to 2012 and the relationship between serovars changing and antimicrobial resistance. BMC Vet Res, 15, 108 .

8. El-Sharkawy H, Tahoun A, El-Galiel A, et al (2017): Epidemiological, molecular characterization and antibiotic resistance of Salmonella enterica serovars isolated from chicken farms in Egypt. Gut Pathog, 9, 8.

9. European Food Safety Authority (EFSA) (2019): The European Union One Health 2018 zoonoses report. EFSA J, 17, e05926.

10. European Food Safety Authority (EFSA) (2019): Salmonella control in poultry flocks and its public health impact. EFSA J, 17, 5596.

11. European Food Safety Authority (EFSA) (2020): The European Union summary report on antimicrobial resistance in zoonotic and indicator bacteria from humans, animals and food in 2017/2018. EFSA J, 18, e06007.

12. Gal-Mor O, Boyle EC, Grassl GA (2014): Same species, different diseases: how and why typhoidal and nontyphoidal Salmonella enterica serovars differ. Front Microbiol, 5, 1-10.

13. Gosling RJ, Breslin M, Fenner J, et al (2016): An in-vitro investigation into the efficacy of disinfectants used in the duck industry against Salmonella. Avian Pathol, 45, 576581.

14. Gradel KO, Rattenborg E (2003): A questionnaire-based, retrospective field study of persistance of Salmonella Enteritidis and Salmonella Typhimurium in Danish broiler houses. Prev Vet Med, 56, 267-284.

15. Gu G, Strawn LK, Zheng J, et al (2019): Diversity and dynamics of Salmonella enterica in water sources, poultry litters, and field soils amended with poultry litter in a major agricultural area of Virginia. Front Microbiol, 10, 2868.

16. ISO (2007): Horizontal method for the detection of Salmonella spp. Amendment 1: Annex D: Detection of Salmonella spp. in animal faeces and in environmental samples from the primary production stage (ISO 6579:2002/A1:2007). International Organization for Standardization, Geneva, Switzerland.

17. ISO (2012): Horizontal method for the detection, enumeration and serotyping of Salmonella - Part 2. Enumeration by a miniaturized most probable number technique (EN ISO/TS 6579-2). International Organization for Standardization, Geneva, Switzerland.

18. ISO (2014): Microbiology of food and animal feed Horizontal method for the detection, enumeration and serotyping of Salmonella - Part 3 (ISO)TR 6579-3
Guidelines for serotyping of Salmonella spp. Available at https://www.iso.org/obp /ui/es/\#iso:std:iso:tr:6579:-3:ed1:v1:en. (Accessed October 01, 2020).

19. ISO (2017): ISO 65791:2017, Microbiology of the food chain-Horizontal method for the detection, enumeration and serotyping of Salmonella - Part 1: Detection of Salmonella spp. International Organization for Standardization, Geneva, Switzerland.

20. Issenhut-Jeanjean S, Roggentin $P$, Mikoleit $M$, et al (2014): Supplement 2008-2010 (no. 48) to the WhiteKauffmann Scheme. Res Microbiol, 165, 526-530.

21. Kardos G, Farkas T, Antal M, et al (2007): Novel PCR assay for identification of Salmonella enterica serovar Infantis. J Appl Microbiol, 45, 421-425.

22. Kiskároly F, Morić I, Dokić L, et al (2017): Development of PCR- based identification of Salmonella enterica serovars. Acta Veterinaria, 67, 271-284.

23. Le Minor L (1992): The Genus Salmonella. In: A Handbook on the Biology of Bacteria: Ecophysiology, Isolation, Identification, Application. (Balows A, Truper HG, Dworkin M, Harder W, Schleifer KH Eds.) 2nd Ed., Springer-Verlag, New York, Berlin, Heidelberg, 27602774.

24. Lublin A, Maler I, Mechani S, et al (2015): Survival of Salmonella enterica serovar Infantis on and within stored table eggs. J Food Prot, 78, 287-292.

25. Lungu B, Waltman WD, Berghaus RD, et al (2012): Comparison of a real-time PCR method with a culture method for the detection of Salmonella enterica serotype Enteritidis in naturally contaminated environmental samples from integrated poultry houses. J Food Prot, 75,743-747.

26. Malorny B, Lofstrom C, Wagner M, et al (2008): Enumeration of Salmonella bacteria in food and feed samples by real-time PCR for quantitative microbial risk assessment. Appl Environ Microbiol, 74, 1299-304.

27. Marin C, Balasch S, Vega S, et al (2001): Sources of Salmonella contamination during broiler production in Eastern Spain. Prev Vet Med, 98, 39-45.

28. Mezal E, Stefanova R, Khan AA (2013): Isolation and molecular characterization of Salmonella enterica serovar javiana from food, environmental and clinical samples. Int J Food Microbiol, 164, 113-118.

29. Nashwa HM, Mahmoud AH, Adawy S (2009): Application of multiplex polymerase chain reaction $(M-$ $P C R$ ) for identification and characterization of Salmonella Enteritidis and Salmonella Typhimurium. J Faculty Vet Med, 5, 2343-2348.

30. National Salmonella Control Programme (2018): General Directorate of Food and Control, Republic of Turkey Ministry of Agriculture and Foresty. Available at https://www.tarim.gov.tr/GKGM/Sayfalar/EN/AnaSayfa.as px. (Accessed 15 July 2018).

31. Nogrady N, Kardos G, Bistyak A, et al (2008): Prevalence and characterization of Salmonella Infantis isolates originating from different points of the broiler chickenhuman food chain in Hungary. Int J Food Microbiol, 127, 162-167.

32. Nogrady N, Toth A, Kostyak A, et al (2007): Emergence of multidrug resistant clones of Salmonella Infantis in 
broiler chickens and humans in Hungary. J Antimicrob Chemother, 60, 645-648.

33. Paniel N, Noguer T (2019): Detection of Salmonella in food Matrices, from conventional methods to recent aptamer-sensing technologies. Foods, 8, 371.

34. Park H-J, Chon J-W, Lim J-S, et al (2015): Prevalence analysis and molecular characterization of Salmonella at different processing steps in broiler slaughter plants in South Korea. J Food Sci, 80, 2822-2826.

35. Pate M, Micunovic J, Golob M, et al (2019): Salmonella Infantis in broiler flocks in Slovenia: the prevalence of multidrug resistant strains with high genetic homogeneity and low biofilm-forming ability. BioMed Res Internat, 2019, 1-13.

36. Pavic A, Groves PJ, Cox JM (2011): Development and validation of a drag swab method using tampons and different diluents for the detection of members of Salmonella in broiler houses. Avian Pathol, 40, 651-656.

37. Pelkonen S, Romppanen E-L, Siitonen A et al (1994): Differentiation of Salmonella serovar Infantis isolates from human and animal sources by fingerprinting IS200 and 16S rrn loci. J Clin Microbiol, 32, 2128-2133.

38. Pulido-Landínez M (2019): Food safety: Salmonella update in broilers. Anim Feed Sci Technol, 250, 53-58.

39. Rahmani M, Peighambari SM, Svendsen CA, et al (2013): Molecular clonality and antimicrobial resistance in salmonella enterica serovars Enteritidis and Infantis from broilers in three Nothern regions of Iran. BMC Vet Res, 9, 66.

40. Raseta M, Djordjevic V, Vidernovic D (2015): Contamination routes of $S$. Infantis in food chain of broiler meat production and its significance for public health. Proce Food Sci, 5, 254-257.

41. Rozen S, Skaletsky HJ (2003): Primer3 on the WWW for general users and for biologist programmers. 365-386. In: S Misener, SA Krawetz (Eds), Bioinformatics Methods and Protocols: Methods in Molecular Biology. Humana Press, Totowa, New Jersey, USA.
42. Schrank IS, Moresv MAZ, Costa JLA, et al (2001): Influence of enrichment media and application of a PCR based method to detect Salmonella in poultry industry products and clinical samples. Vet Microbiol, 82, 45-53.

43. Shanmugasamy M, Velayutham T, Rajeswar J (2012): InvA gene specific PCR for detection of Salmonella from broilers. Vet World, 4, 562-564.

44. Siala M, Barbana A, Smaoui S, et al (2017). Screening and detecting Salmonella in different food matrices in Southern Tunisia using a combined enrichment/Real-Time PCR method: Correlation with conventional culture. Method Front Microbiol, 8, 2416.

45. Terentjeva M, Avsejenko J, Streikisa M, et al (2017): Prevalence and antimicrobial resistance of Salmonella in meat and meat products in Latvia. Ann Agri Environ Med, 24, 317-321.

46. Voss-Rech D, Vaz CSL, Alves L, et al (2015): A temporal study of Salmonella enterica serotypes from broiler farms in Brazil. Poult Sci, 94, 433-441.

47. Wang J, Zheng R, Wang J (2007): Risk assessment of Salmonella in animal derived food. Chinese $\mathrm{J}$ Anim Quarantine, 24, 23-25.

48. Wang X, Biswas S, Paudyal N, et al (2019): Antibiotic resistance in Salmonella Typhimurium isolates recovered from the food chain through National Antimicrobial Resistance Monitoring System between 1996 and 2016. Front Microbiol, 14, 1748.

49. Wedderkopp A, Gradel KO, Jorgensen JC, et al (2001): Pre-harvest surveillance of Campylobacter and Salmonella in Danish broiler flock: a 2-year study. Int J Food Microbiol, 68, 53-59.

50. Wierup M, Wahlstrom H, Lahti E, et al (2017): Occurrence of Salmonella spp.: a comparison between indoor and outdoor housing of broilers and laying hens. Acta Vet Scand, 59, 13.

51. Yum-Bir (2018): Poultry sectoral data, 2018. Available at https://www.yum-bir.org/userfiles/file. (Accessed 10 March 2019). 